\title{
The Institutionalization of Unethical Behavior
}

LaRue T. Hosmer

\begin{abstract}
There is a possibility that the ethical problems that have recently surfaced at General Electric, E. F. Hutton and General Dynamics are not simple anomalies, but the direct result of corporate pressures on individual managers. The author looks at the nature of these pressures, which come from the strategic planning systems in use at most large corporations, and concludes that the current emphasis upon improvements in competitive positioning have led many managers to take actions that are directly contrary to the moral standards, either explicit or implied, of their organizations.
\end{abstract}

During the spring and summer of 1985 , there were several highly visible and, to those of us concerned with business ethics, highly disturbing disclosures of inappropriate managerial behavior in large companies. General Electric, a firm with a reputation for excellence and one inevitably included on lists of "best managed" companies, pleaded guilty to a charge of defrauding the government on a missilewarhead contract. The defense fraud conviction cost the company $\$ 2$ million in criminal penalties. ${ }^{1}$ In a

LaRue Hosmer is Professor of Policy and Control at the Graduate School of Business Administration of the University of Michigan. He was the founder and president of a company that manufactured heary equipment for sawmills and papermills. He has been teaching Business Policy, Small Business Management and Entrepreneurship at The University of Michigan since 1972, with visiting appointments during that period at Stanford and Yale. His research interests are in managerial ethics, corporate responsibility and strategic implementation. He is the co-author of The Entrepreneurial Function (Prentice-Hall, 1977) and the author of Strategic Management: Text and Cases on Business Policy (Prentice-Hall, 1982), Formation Planning (McGraw-Hill, 1984), Managerial Ethics (in press) and Making Strategy Work (in press). lesser known but equally disturbing case, General Electric was fined $\$ 100,000$ and told to absorb $\$ 900,000$ of overcharges in a civil suit involving a satellite contract. ${ }^{2}$

E. F. Hutton, one of the largest and most respected of the retail brokerage firms, pleaded guilty to a check-overdraft scheme that allegedly defrauded approximately 400 smaller banks. The intentional overdrafts gave Hutton the interest-free use of up to $\$ 250$ million, and is said to have cost the banks as much as $\$ 8$ million. The company was fined $\$ 2.75$ million, and ordered to make restitution to the banks. ${ }^{3}$

General Electric and E. F. Hutton were the most publicized of the 1985 investigations into fraudulent practices, but they were not the only examples that could be found. It has even been alleged that G.E. and Hutton were selected for prosecution because they were well known, and well respected, and consequently the cases would be well publicized. "G.E. was sacrificed in some sense", John Van Naanen of the Sloan School of Management at M.I.T. is quoted as saying in the Wall Street Journal. "You could have found the same thing at a dozen other companies". ${ }^{4}$

Which are those other companies? Many of them are defense contractors. In June, Rep. John Dingle of Michigan released a list of firms accused of defrauding the government in military purchases. The list had been provided by the Pentagon Inspector General, and included McDonnell Douglas for cost mischarges, Rockwell International for labor overcharges, General Dynamics for improper billings and cost mischarges, Boeing for labor overcharges and product substitutions, United Technologies for gratuity payments, subcontractor kickbacks, cost mischarges and defective pricing. There is no need to detail all of the allegations. It is sufficient to say that 
all ten of the largest defense contractors faced federal criminal investigations during the summer of $1985 .{ }^{5}$

Why has this occurred? This is the interesting issue, for those of us concerned with the ethics of management, and there have been a number of explanations of varying sophistication. Mr. Lester Crown, Executive Vice President of General Dynamics, member of the Board of Directors, and representative of the family that owns roughly $22 \%$ of the common stock of that company, blamed the situation in his company upon the ineffective auditing procedures employed by the Department of Defense. $^{6}$

General Dynamics had been accused of adding $\$ 63$ million of improper overhead expenses, including country club memberships and dog kennel fees, to defense contracts during the period 1979 to 1982. In explanation, Mr. Crown said, "All these things were put in for reimbursement. The D.C.A.A. (Defense Contract Administrative Auditor) looked at them, then the contracting officer. They then knocked out certain percentages. That is either a very efficient or a very lazy way. You end up, with the passage of time, throwing more and more in, because you know a certain percentage of it comes out in the end."

Mr. Crown felt that the major error made by General Dynamics was not pressing for improvements in the auditing methods of the Pentagon. "Is it (the Pentagon auditing procedure) a right way? No, I don't think so. It should be more specific about individual charges. Perhaps we should have had the foresight and ingenuity to say it should have been changed."

Mr. Crown also added the familiar excuse that senior executives were unaware of the problem. "You aren't talking about ethics. I don't think anyone in the corporate office knew how these things were being charged. It was done on a local basis. The thing got sloppy, but not with any thought at the top." Mr. Crown did not explain why the internal auditing procedures at General Dynamics, nor the external auditing required by law and performed by Arthur Anderson and Company, had not revealed the problem prior to the Congressional investigation.

Another explanation blamed the non-competitive nature of the weapons procurement process, and the "anything goes" attitude that seemed to permeate that process. The New York Times, in an editorial, stated: ${ }^{7}$

General Electric is a household word. It's the nation's largest maker of electrical appliances. Its management techniques are studied worldwide. Its automated factories are models of advanced design. Yet this week it pleaded guilty to defrauding the Air Force of $\$ 800,000$ by forging workers' time cards on a contract for upgrading the warheads on Minuteman missiles.

What made a superb company stoop to picking the public's pocket, and for so petty a gain?

Seeking the causes of crime outside the criminal may not be fashionable, but it's somehow hard to envisage a group of G.E. managers deciding out of the blue that it was a good day to rob the Air Force. They surely operated in a culture of sleaze and borderline morality in which such behavior is deemed acceptable

That's not the culture of General Electric, but it's coming more and more to look like the pattern of acceptable behavior among certain defense contractors. Though G.E. is the nation's sixth-largest defense contractor, military work counts for only 18 percent of its business.

Despite recent attempts at reform, the Pentagon has destroyed competition, preferring sole-source contracts in which officials are free to alter and gold-plate weapons regardless of cost. The same officials then go to work for the contractors they cosset. Through contractor lobbying, Congress is made a party to a system greased by vast sums of money, in which weapons are procured by favors and influence, not by open competition.

The New York Times did not explain how open competition could be made applicable to the design of complex weapon systems that require extreme technological capability for development, and extreme asset specificity for manufacture. The New York Times also did not explain how, in essence, exactly the same pattern of fraudulent exploitation appeared at E. F. Hutton, in the retail brokerage industry that has no connection to defense and no lack of competition.

E. F. Hutton was paired with General Electric in the introduction to this paper to illustrate the impartiality of managerial dishonesty. Defrauding of customers, workers, suppliers and the public seems to occur in both the military and civilian sectors of the economy. We do not know the extent of the fraudulent practices in the civilian sector, of course, for we do not have the benefit of Congressional and 
Department of Justice investigations - except in the unusual instance of E. F. Hutton - but let me cite some anecdotal evidence. All of us who teach managerial ethics at Schools of Business Administration are occasionally contacted by former students, troubled about particular practices that seem to be accepted as ordinary business routines within their companies. These contacts often seem to be inspired by current news stories. Here are summaries of three recent contacts, obviously prompted by the publicity given to E. F. Hutton:

1. A prior student, working in data processing and operations management at the dividend disbursement section of a large bank, said that it was common practice not to respond to the first inquiry from a company stock-holder regarding non-receipt of a dividend payment. Individual investors, particularly older people, lose their checks, or they move between winter and summer homes, and the Post Office may not forward their checks. Nonresponse to the first inquiry permits the bank to have use of the funds for 45 to 60 additional days, until a second inquiry is sent.

2. A prior student, working in the purchasing department of an automobile manufacturer, said that it was common practice to delay payments to small parts suppliers beyond the normal 30 day terms. Smaller suppliers have no effective way of complaining, beyond discontinuing the business relationship. It is interesting that the E. F. Hutton overdrafts were drawn on smaller banks, that again had no effective means of rectifying the situation.

3. A prior student, working as a commercial loan officer in a large bank, said that while it was not a common practice, the bank would arrange, as part of their normal cash management services, to have customer checks drawn on accounts at remote locations; this, of course, delayed the actual payment of the funds, and increased customer bank balances. This person also said that customer overdrafts on those accounts were "accepted" as a cost of business. "E. F. Hutton is only one of many companies that has discovered this cheap form of financing" was the statement made to me, in confidentiality.

These three practices are, perhaps, not illegal, but they do have an adverse impact upon stockholders, suppliers and creditors without their consent, and consequently there is an ethical element. Why do they occur, apparently without examination or concern at the companies involved? We have looked at two explanations - lack of auditing and lack of competition - that seem not to be applicable in the present instances. Let us look at a third - benefits to the corporation, not to the individual - from the Wall Street Journal ${ }^{8}$ that will serve to introduce the major argument of this paper:

But, rules and lectures are ineffective against an excess of loyalty to an employer. Unlike former LTV Corp. Chairman Paul Thayer or Tennessee banker Jake Butcher, both of whom recently drew prison sentences for illegally using their positions to enrich themselves, the G.E. managers who have violated laws did so to bolster the company's fortunes, not their own.

The argument that unethical behavior is a consequence of an "excess of loyalty to an employer" and a desire to further the employer's interests, not the individual's, even at the expense of stockholders, suppliers, employees and creditors, in my opinion totally misconstrues the position in which many, if not most, middle level managers are placed today. There are personal benefits to unethical behavior in middle management. These personal benefits come from very specific provisions in the organizational structure and managerial processes currently used by large firms. Let us look at these "structural" causes of unethical behavior.

Most large companies, today, are diversified. In a landmark research project on corporate strategy (the first to use large scale data to relate economic performance to corporate strategy and organizational structure), Richard Rumelt of U.C.L.A. ${ }^{9}$ found that by $1969,93 \%$ of America's 1000 largest firms were diversified (operating in more than one industry). Subsequent studies have shown that the 93\% figure has increased. ${ }^{10}$ In the major finding of his work, Prof. Rumelt confirmed the earlier historical analysis of Alfred Chandler ${ }^{11}$ that a divisionalized structure followed a diversified strategy, and he demonstrated that this strategy-structure sequence was related to 
the improved economic performance of firms within his sample.

The divisionalized structure, of course, divides a company into a series of product divisions, each of which is responsible for the financial performance of a given product or product line. A divisionalized structure of this type, at the date of the Rumelt study, was generally decentralized: authority for product, market and process changes was allocated to the divisional management who were also held responsible for economic performance.

There are two major problems with the divisionalized, decentralized type of organizational structure. $^{12}$ Firstly, interrelationships between the divisions - in products, markets, processes or technologies - cannot be utilized as the basis for economies of scale or economies of scope due to the separate nature of the divisions. For example, three divisions all using fractional horsepower motors in their product designs, or all using industrial wholesalers for their distribution channels, have no incentive in a decentralized structure to combine their activities. And, corporate management in the decentralized structure had no control over the divisional strategies until after an outstanding success or absolute failure had occurred. Changes in the management of diversification were needed.

General Electric led in the development of new methods for the management of diversity. G.E., of course, is almost the archetype of a diversified firm, with numerous products, multiple markets and various processes, and in the early 1970s it was organized in a decentralized structure, with approximately 250 product divisions grouped by industry type and evaluated by financial performance. Corporate executives, however, were concerned that despite substantial sales increases and continual technical developments, profits remained almost constant in absolute terms, and actually declined as a percentage of sales. The corporate-level executives were also dismayed by their inability to influence the strategy of the product division competing in the mainframe computer market, which eventually resulted in a write-off of nearly $\$ 300$ million in developmental expenses and facility investments. It was felt that a new method of strategic planning was needed, to combine related divisions and to control divisional strategies.
The strategic planning method developed by General Electric was termed a portfolio model since it evaluated each product-market-process unit in the company as an investment that could be increased, maintained, or decreased over time, similar to the portfolio or assortment of investments in stocks and bonds held by a mutual fund. ${ }^{13}$ The product-market-process units at General Electric were termed "strategic business units", or "SBUs"; they consisted of related product divisions that had an ability to act independently in an industry with known competitors through a clearly defined strategy. Because each SBU combined related divisions, functional executives within an SBU could achieve economies of scale and economies of scope through cooperative actions. Because each SBU acted independently within an industry (that is, without the need for relying upon input materials or output sales from other sections of the company), senior executives within the firm could hold the managers and staff of an SBU solely responsible for short-term performance. Because each SBU was dependent upon the corporation for finance, senior executives could review and direct the long-term strategy of an SBU through resource allocation, using a corporate planning model rather than a capital budgeting process. The 250 decentralized product divisions at General Electric became 73 semi-centralized strategic business units.

The central concept of the semi-centralized corporate planning model developed by General Electric was that each strategic business unit differed on two basic dimensions: the attractiveness of the industry, and the strength of the company within that industry. It was felt that each strategic business unit could be measured on those two dimensions, and then compared. As a result of the comparison, corporate resources could be channeled to the divisions that combined industry attractiveness and company strengths because these were felt to be the divisions with the greatest probability of competitive success and increased profitability.

The attractiveness of the industry was measured on a multiple factor scale that included such inputs as the overall size of the market, annual growth, historical profitability, competitive intensity, etc. See Figure 1 for a listing of the factors, and an example of the measurement process. The factors were weighted (by percentage) and then the business unit 


\begin{tabular}{lccc}
\hline & Weight & Measurement & Value \\
\hline Overall size & 0.20 & 4.00 & 0.80 \\
Annual growth & 0.20 & 5.00 & 1.00 \\
Historical margins & 0.15 & 4.00 & 0.60 \\
Competitive intensity & 0.15 & 2.00 & 0.30 \\
Technological & & & \\
$\quad$ requirements & 0.15 & 3.00 & 0.45 \\
Inflationary vulnerability & 0.05 & 3.00 & 0.15 \\
Energy requirements & 0.05 & 2.00 & 0.10 \\
Environmental impact & 0.05 & 1.00 & 0.05 \\
Social/political/legal & Must be & & - \\
& acceptable & & \\
& $\mathbf{1 . 0 0}$ & & 3.45 \\
& & & \\
\hline
\end{tabular}

\begin{tabular}{lccc}
\hline & Weight & Measurement & Value \\
\hline Market share & 0.10 & 2.00 & 0.20 \\
Share growth & 0.15 & 4.00 & 0.60 \\
Product quality & 0.10 & 4.00 & 0.40 \\
Brand reputation & 0.10 & 5.00 & 0.50 \\
Distribution network & 0.05 & 3.00 & 0.15 \\
Promotional effectiveness & 0.05 & 2.00 & 0.10 \\
Productive capacity & 0.05 & 3.00 & 0.15 \\
Productive efficiency & 0.05 & 2.00 & 0.10 \\
Unit costs & 0.15 & 3.00 & 0.45 \\
Material supplies & 0.05 & 5.00 & 0.25 \\
R\&D performance & 0.10 & 4.00 & 0.80 \\
Managerial personnel & 0.05 & 4.00 & 0.20 \\
\cline { 2 - 4 } & 1.00 & & 3.90 \\
\hline
\end{tabular}

Company strength within the industry

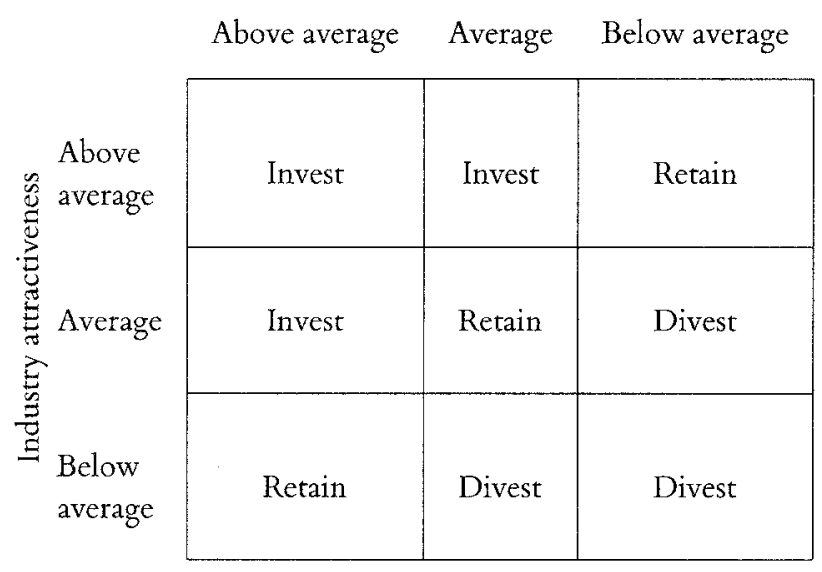

Fig. 1. Factors, weights and measures for the General Electric planning matrix.

Source: LaRue Hosmer, Strategic Management: Text and Cases on Business Policy, Prentice Hall, 1982, pp. 311-12. was measured (on a comparative rather than absolute scale of 1 to 5) for each factor to obtain an approximate value that could be summarized, and used to evaluate the competitive posture of the SBU.

The strength of the business unit within the industry was also measured on a multiple factor scale that included such elements as market share, share growth, product quality, brand reputation, etc. Again, these factors were weighted and the business unit measured along cardinal scales to obtain a summary figure.

Owing to the subjective nature of the weights that were applied to each of the factors, and to the inexact method of measurements along comparative rather than absolute scales, the summary figures for the attractiveness of the industry and the strength of the company within that industry were not used directly to evaluate each business unit. That is, a strategic business unit that measured $3.45 \times 3.90$, as in the example in Figure 1, was not automatically considered to be "better", or more likely to receive funding for further growth, than one that measured $3.35 \times 3.80$, or even $3.45 \times 4.00$. Instead, all strategic business units were grouped along each dimension, with one-third above average, one-third average, and one-third below average, and then they were visually displayed on a simple nine-cell matrix, again illustrated in Figure 1.

Business units that were above average on one of the dimensions of the General Electric planning model, and at least average on the other dimension, were considered to be optimal candidates for corporate investment, and accelerated growth. Business units that were below average on one of the dimensions, and no better than average on the other, were felt to be prime candidates for disinvestment, and eventual sale or liquidation. The balance of the business units were destined to be maintained at approximately the existing sales level and capital supply until either the industry's attractiveness or the company's strength within that industry changed, leading then to increased investment and growth, or to gradual devestment, and sale.

The planning model proposed by the Boston Consulting Group, though considerably better known due to "catchy" phrases and an active promotional campaign, is in reality an offshoot of the one developed by the General Electric Company. ${ }^{14}$ The B.C.G. model, shown in Figure 2, avoids the 


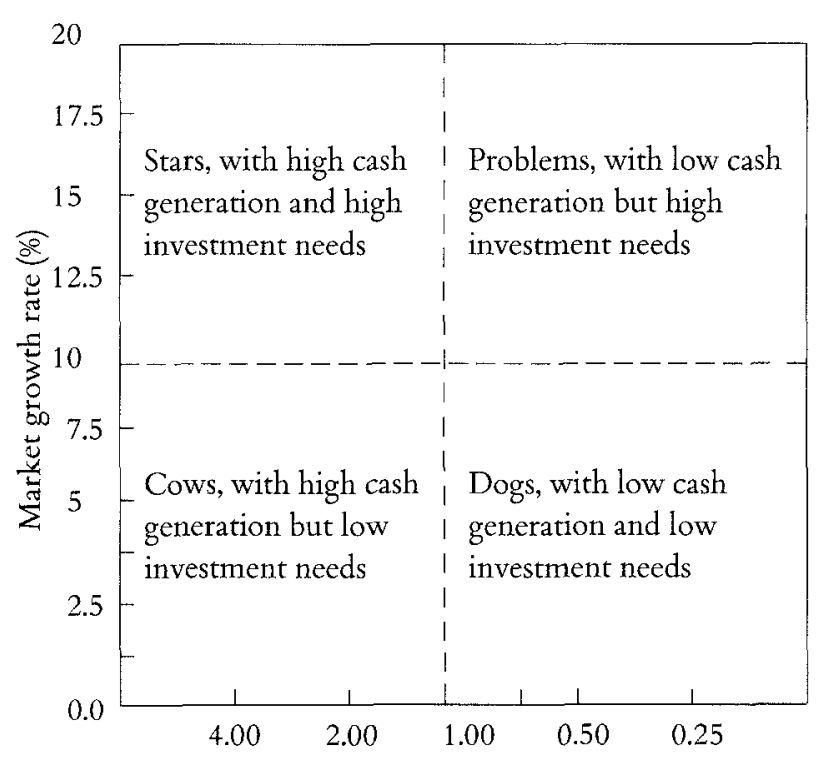

Market share relative to the largest competitor

Fig. 2. Market share and market growth relationships for the Boston Consulting Group planning matrix.

Source: LaRue Hosmer, Strategic Management: Text and Cases on Business Policy, Prentice Hall, 1982, p. 312.

problems of subjective weighting and comparative measures by assuming that a single statistic can serve as the surrogate for industry attractiveness, and that another single statistic can serve as the surrogate for the divisional strengths within the industry.

The Boston Consulting Group believes that the growth rate of the market, in percentage terms, can be used as a summary figure for the attractiveness of the industry, since high growth rates tend to be associated with high gross margins and low competitive pressures. High growth rates generally occur in the early stages of the product life cycle, before intensive competition affects industry prices, margins and profits. The Boston Consulting Group also believes that the share of the market, again expressed in percentage terms, can be used as a summary figure for the competitive position of the company within the industry because high market share tends to be associated with low production and distribution costs. The relationship between high market share and low competitive cost in the B.C.G. model is felt to be partially the result of the economies of scale that bring a constant decrease in average unit costs with each increase in annual production volume, but it is thought primarily to be the result of the experience curve that brings a continual decrease in average unit costs with each doubling of the cumulative production volume. The relationship between market share and market growth is generally portrayed in the B.C.G. model on a 4-cell matrix, with the familiar "star", "cash cow", "problem child" and "dog" categories.

What do "star", "cash cow", "problem child" and "dog" categories, or for that matter, "above average", "average" and "below average" rankings have to do with unethical managerial behavior? They are determinant, given the uses of the strategic planning models by senior management. Think for a minute of the possibility of your business unit being ranked below average on either industry attractiveness or company strength; what will happen to that unit? Lack of investment, and a "wait and see" attitude on the part of corporate management is the best you can expect; disinvestment, and eventual sale or dissolution, is the most likely outcome. What will happen if your business unit is positioned in the dog category? Your unit will be, if we continue to use the BCG barnyard lexicon, "harvested", generally through sale of the unit or dissolution of the assets.

Is it propitious to a person's career to be "harvested"? There is little empirical data here, but there is substantial anecdotal evidence, all of which seems to indicate that the sale or dissolution of a business unit often brings personal trauma as executive teams are broken up, and a very real chance of dismissal in the subsequent cost cutting efforts. ${ }^{15}$

Is it possible to avoid the "below average" rankings or the "cash cow" and "dog" categories? Yes, simply by maintaining quarterly profits as a return on investment at a "satisfactory" level. In the General Electric planning matrix, profitability has a direct influence on the measurement of industry attractiveness through the input factors of historical margins and competitive intensity, accounting for $30 \%$ of the weightings. Profitability has an indirect influence on the measurement of company strengths through the input factors of product quality, brand reputation, promotional effectiveness and production efficiency, accounting for $35 \%$ of the weightings. The influence on company strengths is indirect because high profits are felt to be an indication, not a direct measure, of high product quality, good brand recognition, etc. 
In the B.C.G. planning matrix, high profits are assumed to be the result of high market share and high market growth. Consequently, the markets served by a given strategic business unit are further segmented and redefined until the profit, growth and share figures are consistent. This is not as unprofessional as it may seem; the need for consistency forces detailed examination of market segments and growth rates, and provides a better understanding of the competitive position of a firm. For example, Mercedes-Benz has a very small share of the slow growing total automobile market in the U.S.; a higher share of the more rapidly growing import automobile market; and the highest share of the most rapidly growing luxury automobile market both in the U.S. and worldwide.

Can the managers within a strategic business unit alter the recorded profit of that unit, and consequently the position of that unit on the planning matrix? Yes, it is all too easy over the short-term. In the non-competitive defense industry, it is possible to change labor charges from a fixed-price to a negotiated-price portion of the contract, as was done by General Electric. Or, it is possible to switch wages from indirect to direct labor so that higher overhead rates may be allocated, as was done at McDonnell Douglas. Or, it is possible to simply add more overhead items, as was done at General Dynamics.

In the competitive brokerage, automotive supply and commercial banking industries, it is possible to change the amount of capital employed by a strategic business unit. Most companies now charge for both working capital and fixed capital, and those charges constitute a major expense item. By reducing the amount of capital recorded against a business unit, it is possible to improve both the numerator and the denominator of the return on investment ratio. $(\mathrm{ROI}=$ profits/capital employed) The branch offices at E. F. Hutton, the dividend disbursement unit of the bank, the assembly division of an automobile company and the customers of the cash management service all were reducing the amount of capital charged to their organizational units, and improving their return on investment ratios.

What can be done to prevent these practices? They may or may not be illegal, but the ones we have discusssed in the competitive industries do harm the smaller banks, the smaller stockholders, the smaller suppliers. No office manager at E. F. Hutton attempted a deliberate overdraft against Citicorp, and I think it safe to assume that no dividend disbursement officer has ignored the first inquiry from Morgan Stanley or Goldman Sachs. Lastly, my informant from the automobile industry admits that large suppliers are paid promptly. The Pentagon, of course, is not small, but apparently many defense contractors felt that the weapons procurement process was too complex and cumbersome for effective control of labor and overhead billings, and so provided an opportunity for exploitation.

What can be done? General Electric Company has taken three publicized actions since the conviction. ${ }^{16}$ They have strengthened the policy manual to ensure that strict accounting procedures are followed in government contracts. They have appointed an ombudsman authorized to investigate any allegations of wrongdoing within the company. They have issued a series of statements stressing that unethical behavior will not be tolerated. The Chairman of General Electric, John Welch, spoke out clearly on "abuses of integrity" in a story from the Wall Street Journal: ${ }^{17}$

Lest anyone doubt the seriousness of G.E.'s intent, Mr. Welch issued a stern warning in a videotape being shown to employees. Pressure to meet corporate goals won't excuse misbehavior, he says, adding that such pressures are intensifying as G.E. battles competitors around the globe. He also urges employees to come forward with their suspicions of wrongdoing. "Whistle blowing, speaking out, telling it like it is, is part of what we're after', he says. 'I can assure anybody who wants to talk about abuses of integrity in this company that they will be welcomed'.

Will these actions be effective? In the article from the Wall Street Journal, ${ }^{18}$ it was stated that, "Workers at the Philadelphia missile-warhead plant where the fraud occurred confirm that G.E. is tightening accounting procedures and checking time-card charges to prevent falsifications. But they stress that plant employees were fully aware of correct procedures long before the fraud occurred."

The appeal for "whistleblowers" may be no more effective than the tightening of accounting procedures. All of the managers within an SBU are affected by the rankings of their unit. Most of the managers probably were not aware of the exact methods used to improve those rankings at G.E. and E. F. Hutton, and few of the managers actually participated in 
those schemes, but most probably were grateful. An "us against them" attitude has developed in the strategic business units at most corporations - the operating people being pushed for performance improvements against the senior executives and corporate staff doing the pushing - and I assume that the loyalties of the business unit people are reasonably well established. Gratitude and loyalty are powerful forces to add to the normal reluctance to inform on others.

What is needed to eliminate the structural forces that push managers towards unethical decisions and actions? I have two suggestions. The first is to emphasize analytical rather than strategic planning. Planning, control and motivation are related - see Figure $31^{19}$ Divisional strategic planning that is based upon an analysis of the comperitive conditions of the industry, the specific strengths and weaknesses of the firm, and the anticipated trends in the economy can be translated into more accurate resource allocations in the program planning stage, and more realistic

\begin{tabular}{|c|c|c|}
\hline & & Environmental assumptions \\
\hline & Strategic planning & Organizational resources \\
\hline & (method of competition) & Managerial intentions \\
\hline & & Strategic alternatives \\
\hline & & Net present value \\
\hline Planning & Program planning & Internal rate of return \\
\hline system $^{\circ}$ & (allocation of resources) & Cost-benefit analysis \\
\hline & & Competitive position analysis \\
\hline & & Revenue forecasts \\
\hline & Budgetary planning & Expense estimations \\
\hline & (projection of results) & Numerical measures \\
\hline & & Descriptive standards \\
\hline & & Cost accumulation systems \\
\hline Control & Operational accounting & Cost allocation systems \\
\hline system & (recording of performance) & Responsibility centers \\
\hline & & Transfer prices and shared costs \\
\hline & & Organizational control \\
\hline & Comparative cvaluation & Program control \\
\hline & (analysis of variances) & Management control \\
\hline & & Operational control \\
\hline & & Perceptual response \\
\hline Motivation & Otganizational response & Financial response \\
\hline system & (design of incentives) & Positional response \\
\hline & & Personal response \\
\hline & & Personal influence \\
\hline & $\begin{array}{l}\text { Individual response } \\
\text { (actions and decisions) }\end{array}$ & $\begin{array}{l}\text { Interpersonal influence } \\
\text { Social influence } \\
\text { Cultural influence }\end{array}$ \\
\hline
\end{tabular}

Fig. 3. Relationship of planning, control and motivational systems in corporate management.

Source: LaRue Hosmer, Strategic Management: Text and Cases on Business Policy, Prentice Hall, 1982, p. 566. achievement targets in the budgetary planning process. Strategic planning that avoids the company, industry and economy appraisal in favor of establishing arbitrary financial goals, following the directives of the senior executives, can lead to inappropriate resource allocations, unachieveable performance standards, and the temptation to cheat. Listen to this statement that describes directive rather than analytical strategic planning from a very recent issue of Business Week: ${ }^{20}$

Then Begel (Thomas Begel, Chief Executive Officer of the Pullman Company, which has just acquired Peabody International, a manufacturer of road graders, dump trucks and other construction equipment) can start improving Peabody. He wants margins to reach 5\% after taxes, matching Pullman's. He also wants a return on equity of over $15 \%$ - quite a change from the $2 \%$ Peabody posted in the first half of fiscal 1985. First, though, Begel intends to "take a hard look at everything" Peabody has. "If there are any losers in there, they're going to become winners, or they're going to be consigned to oblivion", predicts Prezelski (Frank Prezelski, financial analyst at Shearson. Lehman Brothers, the analyst assigned to the Pullman Company, who presumably made this statement after meeting with senior executives).

What are the "losers" at Peabody going to do? They compete with low margin products in slow growth markets against well established firms, both domestic and foreign. In any portfolio planning model, they would find themselves in the "below average" ranking or "dog" category. There are few legitimate means of increasing the return on equity quickly, given that competitive position. There are, however, numerous means of raising the return on equity that may or may not be what Thomas Begel and Frank Prezelski expect, and what suppliers, banks, employees and customers consider to be "fair".

My other suggestion, and this is certainly related to the need for more analytical and less directive strategic planning, is to change the corporate management style. The corporate management style at many if not most large companies today is to push: to push for greater revenues, higher profits, larger returns. No one says "and we don't care how you get them", but was that statement not previously implied at General Electric and E. F. Hutton, and is that statement not now implied at Peabody International?

It is very instructive that the problems at General Electric have occurred under the current C.E.O., 
John Welch, not with the prior C.E.O., Reginald Jones. Mr. Welch led the 1984 listing in Fortune's "The Toughest Bosses in American. ${ }^{21} \mathrm{He}$ is known, according to that article in Fortune, as "Neutron Jack", referring to the alleged capability of a neutron bomb to save the buildings but get rid of the people. Mr. Jones, on the other hand, leads the individuals described in the new book by Harry Levinson and Stuart Rosenthal, C.E.O.: Corporate Leadership in Action. ${ }^{22}$ Here are two personal quotations, one from each source (Welch, ${ }^{23}$ Jones $^{24}$ ) that are very indicative of the management style of each individual:

The role for the mediocre is clearly short-lived.

G.E. has a unique culture. It's a family. We enjoy each other. We don't lose many in the family of G.E. people. We're so supportive of each other we try desperately to save an individual who has failed, by placing him in a job that better matches his capacities, in order that the individual can make a contribution to the organization. We save many people. There is a renaissance of these people in many instances.

There is a need for a corporate management style that pulls people to meet future competitive conditions by defining a common objective rather than pushes them to meet current financial projections by installing a comparative planning system. This management style is termed "leadership", and it sets the moral standards for the organization by focusing on the integrity of common purpose. Let me close with two quotations on leadership and morality that I truly like, from Philip Selznick ${ }^{25}$ and Chester Barnard: ${ }^{26}$

Leadership is more than the ability to mobilize personal support; it is more than the maintenance of equilibrium through routine solution of day-to-day problems. Leadership is, the ability to define the ends of group existence, to design an enterprise distinctly adapted to those ends, and to see that the design becomes a reality.

Leadership in organizations is the power of individuals to inspire cooperative personal decisions by creating faith in common understanding, faith in the probability of success, faith in the ultimate satisfaction of personal motives, faith in the integrity of common purpose. Leadership is the moral factor in organizations; it creates the moral code for the organization.

Both Philip Selznick and Chester Barnard are saying clearly - though Chester Barnard says this with characteristically greater precision and elegance - is that common objectives create the values of the firm.
This is a lesson that appears to have been lost in the current methodology of strategic planning.

\section{Notes}

Wall Street Journal, July 5, 1985, p. 4.

2 Ibid.

3 Wall Street Journal, July 12, 1985, p. 1.

4 Wall Street Journal, July 5, 1985, p. 4.

5 Ann Arbor News, June 20, 1985, p. F1.

6 New York Times, June 16, 1985, p. 26F.

7 Ibid, p. 28F.

8 Wall Street Journal, July 5, 1985, p. 4.

9 Richard P. Rumelt, Strategy, Structure and Economic Performance, Division of Research, Graduate School of Business Administration, Harvard University, 1974.

10 See, for example, H. Kurt Christensen and Cynthia A. Montgomery, 'Corporate economic performance: Diversification strategy versus market structure', Strategic Management Joumal 2, 1981, pp. 327-343.

11 Alfred D. Chandler, Strategy and Structure, M.I.T. Press, 1962.

12 LaRue T. Hosmer, Strategic Management: Text and Cases on Business Policy, Prentice-Hall, 1982.

13 For a fuller explanation of portfolio planning at General Electric Company, see Charles W. Hofer and Daniel E. Schendel, Strategy Formulation: Analytical Concepts, West Publishing Company, 1978.

14 For a fuller explanation of portfolio planning at Boston Consulting Group, see Earnest D. Henderson, Perspectives on the Product Portfolio, Boston Consulting Group, 1970.

15 See, for example, 'Help! My company has just been taken over', Fortune Magazine, July 9, 1984, pp. 44-51.

16 New York Times, July 7, 1985, p. 1F.

17 Wall Street Journal, July 5, 1985, p. 4.

18 Ibid.

19 Hosmer, op. cit., p. 566.

20 Business Week, July 22, 1985 , p. 87.

21 'The toughest bosses in America', Fortune Magazine, August 6, 1984, pp. 18-23.

22 Harry Levinson and Stuart Rosenthal, CEO: Corporate Leadership in America, Basic Books, Inc., 1984.

23 'Toughest bosses', op. cit., p. 20.

24 Levinson and Rosenthal, op. cit., p. 20.

25 Philip Selznick, Leadership in Administration, Harper and Row, 1957.

20 Chester I. Barnard, The Functions of the Executive, Harvard University Press, 1983.

Graduate School of Business Administration, The University of Michigan, Ann Arbor, MI 48109, U.S.A. 